\title{
NATURAL AND PREFORMED PHYSICAL FACTORS IN THE IMMUNOREHABILITATION OF PSORIASIS PATIENTS: THE COMPARISON OF EFFECTIVENESS
}

\author{
Olha I.Lemko, Nataliya V. Vantyukh, Ivan S. Lemko \\ Government Institution "The Scientific-practical Medical Centre "Rehabilitation” Health \\ Ministry of Ukraine", Uzhgorod, Ukraine
}

\begin{abstract}
64 psoriasis patients with moderate to severe form of the disease in its stationary stage and associated pathology of main excretory and detoxification systems were investigated. All patients were treated according to two medical complexes (MC). 32 patients were treated according to MC-1, which included sulphide mud applications at temperatures $42^{0} \mathrm{C}$ for 10 30 minutes; artificial brine baths of sodium chloride concentration of $60-120 \mathrm{~g} / 1$ at a temperature of $38^{0} \mathrm{C}$ for 10-30 minutes; artificial ultraviolet irradiation up to 2 biodoses and daily (except Sunday) sessions of haloaerosoltherapy (artificial analogy of salt mine's aerosol) lasting 60 minutes. The treatment duration was 3 weeks. Another group of patients (32 persons) received MC-2. This complex included procedures, according to MC-1, completed with additional internal use of carbonic middle-mineralised boric bicarbonate sodium mineral water Luzhanskaya-7 (the type of Vichy) with the aim of detoxification.

It was found that complex recovery treatment based on non-medicinal factors photobalneotherapy and haloaerosoltherapy (MC-1) has a positive effect on the clinical symptoms of psoriasis and immune status of patients. These positive changes were testified by the corresponding change in the PASI- index (Psoriasis Area and Severity Index), $\triangle$ PASI and dynamics of some immunological parameters. At the same time more pronounced positive dynamics of cutaneous manifestations of psoriasis and higher percent of patients with significant improvement by the end of treatment was achieved under the influence of MC- 2 . In addition, normalization of the neutrophils' absorbtive capasity by the level of PhAN (phagocytic activity of neutrophils - percentage of neutrophils wich ingurgitate latex) and certain improvement of their oxygen-dependent metabolism was observed under the influence of MC-2. The level of $\mathrm{CD}^{+}-\mathrm{CD}^{+}$-lymphocytes had also a tendency to increase in the group of patients who received MC-2 in with contradiction to MC-1. A significant decrease of Blymphocytes level was also observed in this group of patients. The higher indirect imunorehabilitative effect of MC-2 including mineral water Luzhanskaya-7 intake enriched with sulfates may be conditioned by the corrective influence of mineral water on the functional digestive and urinary disorders, reduction of endogenous intoxication manifestations and antigens flow from the gastrointestinal tract to lymphoid follicles.

Conclusion: The received data testified the expediency of non-medicinal supplementation of rehabilitation treatment of psoriasis patients by internal use of bicarbonate sodium mineral water in case of associated pathology and more severe immunological disorders.
\end{abstract} immunity.

Key words: psoriasis, photobalneotherapy, haloaerosoltherapy, mineral water, 


\section{Introduction}

The steady increase of the incidence of psoriasis and high frequency of its severe, complicated forms, as well as a high level of rejuvenation of the disease are the ground for the actuality of scientific investigations concerning new technologies of treatment of patients with psoriasis.

Scientists are still debating on the etiologic and pathogenetic value of different factors as the cause of the psoriasis and its progression. Most of them are inclined to believe that psoriasis is poly-etiological disease [12]. The most frequent provocative factors of the disease are stress, severe acute respiratory syndrome, some medications, professional risks, surgical intervention, skin's trauma etc $[12,13]$. A number of immunological disorders are developing under the influence of triggering factors, mainly in the presence of inherited genetic defects [14]. They stipulate epidermal hyperproliferative changes.

However, skin manifestations, as it is known today, are only the external (superficial) signs of psoriasis. In fact, alongside with the skin lesion changes occur in the inner organs too [7]. This is testified by the high incidence of associated pathology in psoriasis patients $[6,8]$. Lesions of cardiovascular system and development of metabolic syndrome are characteristic for psoriasis patients, but the most frequent is associated pathology of the gastrointestinal tract, hepatic-biliary and urinary systems $[8,10,11,15]$. These changes promote further formation of endogenous intoxication syndrome, which reserves the pathologic process on the skin [2]. Although the non-specific character of intoxication syndrome in various pathological conditions, just the presence of associated pathology determines the pathogenesis and specifies the clinical picture of the main disease, provides intoxication syndrome individual-specific features [5]. Accounting the above mentioned the comprehensive treatment of psoriasis should combine medications for local and systemic therapy. On the stabile stage of the disease rehabilitations measures are expedient.

Natural curative factors with multicomponent mechanism proved to be very effective in the rehabilitation of psoriasis patients [1,9]. They contribute to the inhibition of psoriatic process by influence on the basic pathophysiological mechanisms of the disease. In addition, natural and preformed physical factors may correct associated pathology and have a mild effect on the immune system. A considerable detoxifying effect of drinking mineral waters of different composition was revealed in clinical investigations of patients with pathology of gastrointestinal and urinary systems. This effect was conditioned by the differential corrective influence of mineral waters on the main digestive and urinary dysfunctions [4].

\section{Aim}

The main aim of our work was to develop a technology of rehabilitation treatment in psoriasis patients with associated pathology of the digestive and urinary systems on the base of natural factors of Transcarpathia (sulphide mud, mineral water, brine) and preformed physical agents (artificial ultraviolet radiation and aerosol medium of rock salt haloaerosoltherapy).

\section{Materials and methods}

64 psoriasis patients with moderate to severe form in stationary stage of the disease and associated pathology of main excretory and detoxification systems were investigated. Age of the patients was from 16 till 61 years old $(39,9 \pm 1,5$ years $)$. The average duration of psoriasis was about $15,2 \pm 1,32$ years. All patients had undergone clinical, laboratory and immunological examinations. The dermatological changes were evaluated using PASI index calculation - Psoriasis Area and Severity Index. The clinical efficiency of the therapy was evaluated by 
determining regression of this index under the influence of treatment by calculating the percent value of $\triangle$ PASI using the following

formula:

$$
\triangle \text { PASI }=\text { - } 100 \%
$$

Significant improvement is determined at $\triangle \mathrm{PASI} \geq 76 \%$, improvement - at $26 \% \leq \triangle \mathrm{PASI}$ $<76 \%$, without therapeutic effect - at $\triangle$ PASI value $<26 \%$ of its initial level [2].

Immunological examination included evaluation of non-specific resistance and cellular immunity. The nonspecific resistance was defined using phagocytic activity of neutrophils (PhAN number of active cells per 100 neutrophylls) and phagocytic number calculation $(\mathrm{PhN}-$ number of latex spheres, absorbed by one neutrophile). Inert latex spheres with a diameter of 1,5 microns were used as a test system. In addition, a test was performed with nitroblue tetrazolium (NBT-test). This NBT-test (spontaneous and cycloferon induced) reflected the function of superoxide anion-radical and allowed to evaluate the antibacterial properties of the organism (FR - functional reserve). Cellular immunity was studied using the method of indirect immunofluorescence with monoclonal antibodies to human lymphocytes $\mathrm{CD}^{+}, \mathrm{CD} 22^{+}, \mathrm{CD} 4^{+}, \mathrm{CD} 8^{+}$.

All patients were treated using two medical complexes (MC). 32 patients were treated using $\mathrm{MC}-1$, which included everyday sulphide mud applications at

temperatures $42^{\circ} \mathrm{C}$ for $10-30$ minutes; artificial brine baths of sodium chloride concentration of $60-120 \mathrm{~g} / 1$ at a temperature of $38^{0} \mathrm{C}$ for $10-30$ minutes; artificial ultraviolet irradiation up to 2 biodoses and daily, except Sunday, sessions of haloaerosoltherapy for 60 minutes. The concentration of rock salt aerosol (haloaerosol) maintained within the $15-30 \mathrm{mg} / \mathrm{m}^{3}$ the sizes of the salt particles were 10-30 microns while their content of the air was $50-60 \%$. The treatment duration was 3 weeks with the number of treatment days about 15 - 17 for a course of treatment. Another group of patients (32 persons) received MC-2. This complex included procedures according to MC-1 with additional internal use of carbonic middle-mineralised boric bicarbonate sodium mineral water Luzhanska-7 (the type of Vichy) which has a positive influence on the main detoxifying organs digestive and urinary systems. According to the Kurlov's formula the main composition of the mineral water may be expressed as following:

$\mathrm{HCO}_{3} 97 \mathrm{Cl} 3$

$\mathrm{CO}_{2} 2,2 \mathrm{H}_{3} \mathrm{BO}_{3} 0,081 \mathrm{H}_{2} \mathrm{SiO}_{3}$ 0,051 M 8,1

Dry salt of magnesium sulfate (2-4 g per 1 liter) was added to the mineral water. It has antispasmodic, sedative, diuretic effects, regulates the synthesis and catabolism of nucleic acids, anti-inflammatory, anti-toxic and desensibilizing effect, play role in the regulation of processes of cellular immunity.

23 practically healthy persons formed the control group. The results of all laboratory methods were treated using the

\section{$\mathrm{Na} 90 \mathrm{Ca} 7$ $\mathrm{pH} 6,6 \mathrm{~T} 12,6^{\circ} \mathrm{C}$ \\ method of variation statistics with computer program Excel.}

\section{Results}

Both MC had a positive effect on the skin manifestations of psoriasis - a gradual decrease in colour intensity, scaling, itching, and infiltration of psoriatic plaques with subsequent regression of lesions. These positive changes were reflected in the significant reduction of affected area and PASI index (table 1). 
TABLE 1: Dynamics of cutaneous manifestations in psoriasis patients under the influence of rehabilitation treatment

\begin{tabular}{|l|c|c|c|}
\hline \multicolumn{1}{|c|}{ Indices and their units } & MC-1 $(\mathrm{n}=32)$ & $\mathrm{MC}-2(\mathrm{n}=32)$ & $\mathrm{P}_{1-2}$ \\
\hline The affected area, \% & $9,74 \pm 1,18$ & $9,59 \pm 1,38$ & \\
before treatment & $6,08 \pm 1,04$ & $4,93 \pm 0,65$ & $<0,3$ \\
after treatment & $<0,05$ & $<0,01$ & \\
P & $11,4 \pm 1,23$ & $12,0 \pm 1,42$ & \\
\hline PASI, e.u.(equivalent unit) & $5,08 \pm 0,84$ & $3,86 \pm 0,47$ & $<0,2$ \\
before treatment & $<0,001$ & $<0,001$ & \\
after treatment & $60,5 \pm 3,25$ & $65,5 \pm 2,89$ & $<0,3$ \\
P & & & \\
\hline$\Delta$ PASI, \% & & & \\
\hline
\end{tabular}

Notes: $\mathrm{P}$ - reliability of the difference before and after treatment; $\mathrm{P}_{1-2}-$ reliability of the difference after treatment between both MC.

There was a certain difference between the clinical effects of two MC under the influence of the MC-2 with mineral water intake compared with the MC-1 the tendency of reducing the affected area, index PASI, and the tendency of increasing the rash regression ( $\triangle \mathrm{PASI})$ was observed. After MC-2 a higher percentage of patients discharged with a significant improvement was registered (fig. 1), indicating greater effectiveness of this treatment complex as a result of its corrective influence on the associated pathology and reduction of endogenous intoxication manifestations.

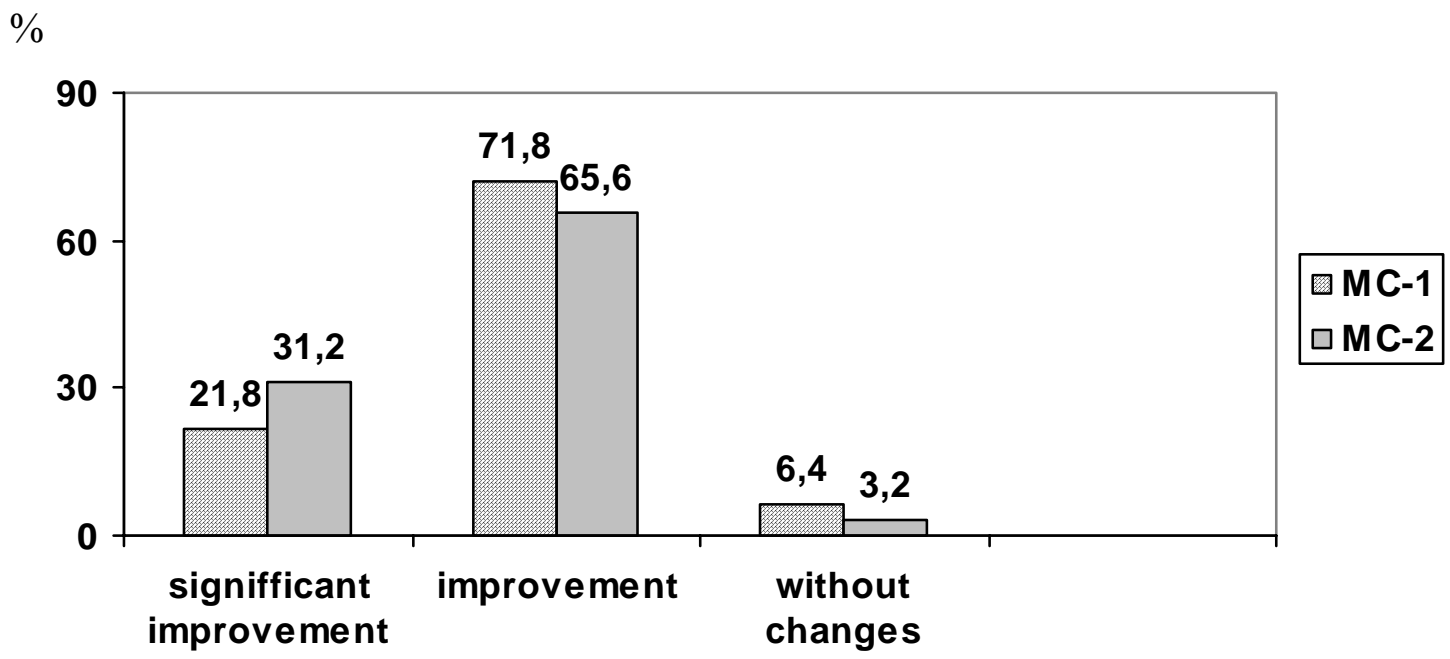

Fig 1. Clinical effectiveness of psoriasis patients' treatment

The positive clinical dynamics was associated with marked immunomodulation effects of both MC (table 2). A tendency of increasing the PhAN and PhN levels was registered indicating some improvement in the neutrophils' absorbance. At the same time, indices of oxygen-dependent metabolism of neutrophiles and theirs functional reserve only slightly varied under the influence of this $\mathrm{MC}$ and remained significantly lower than normal. Normalization of PhAN, spontaneous NBT-test, the levels of stimulated NBT-test, and FR had only a 
tendency to decrease in comparison with the normal values under the influence of MC-2. Comparing two $\mathrm{MC}$ revealed that the magnitude of PhAN after MC-2 was significantly higher than after treatment using MC-1. The percentage of formazanpositive cells in the NBT-test also had a tendency to increase after MC-2 compared with the MC-1. These data indicated a higher immuno-modulation efficiency of MC-2 effects on non-specific defence mechanisms of the organism. This fact may be conditioned by the fact that additional internal use of mineral water (MC-2) promotes improvement of the functional state of the main excretory and detoxification systems. As a result, decrease of antigenic flow from the gastrointestinal tract to lymphoid follicles stipulated a positive effect on the immune system.

TABLE 2: Dynamics of non-specific resistance indexes in patients with psoriasis under the influence of recovery treatment

\begin{tabular}{|c|c|c|c|c|}
\hline Indices and their units & The control group $(n=23)$ & $\begin{array}{l}\mathrm{MC}-1 \\
(\mathrm{n}=32)\end{array}$ & $\begin{array}{l}\mathrm{MC}-2 \\
(\mathrm{n}=32)\end{array}$ & $P_{1-2}$ \\
\hline $\begin{array}{l}\text { PhAN, } \% \\
\text { before treatment } \\
\text { after treatment } \\
\text { P }\end{array}$ & $52,7 \pm 1,50$ & $\begin{array}{c}46,9 \pm 1,11 * * \\
49,8 \pm 1,28 * \\
<0,1\end{array}$ & $\begin{array}{c}48,6 \pm 0,99 * * \\
53,3 \pm 1,18 \\
<0,01\end{array}$ & $<0,05$ \\
\hline $\begin{array}{l}\mathrm{PhN} \\
\text { before treatment } \\
\text { after treatment } \\
\mathrm{P}\end{array}$ & $3,76 \pm 0,08$ & $\begin{array}{c}3,22 \pm 0,07 * * \\
3,39 \pm 0,08 * * \\
<0,1\end{array}$ & $\begin{array}{c}3,28 \pm 0,07 * * \\
3,40 \pm 0,07 * * \\
<0,2\end{array}$ & - \\
\hline $\begin{array}{l}\text { NBT-spontaneous, \% } \\
\text { before treatment } \\
\text { after treatment } \\
\text { P }\end{array}$ & $25,0 \pm 0,75$ & $\begin{array}{l}23,7 \pm 0,59 * * \\
23,8 \pm 0,52 * *\end{array}$ & $\begin{array}{c}23,6 \pm 0,89 * * \\
24,7 \pm 0,66 \\
<0,3\end{array}$ & $<0,3$ \\
\hline $\begin{array}{l}\text { NBT-stimulated, } \% \\
\text { before treatment } \\
\text { after treatment } \\
\text { P }\end{array}$ & $32,8 \pm 0,84$ & $\begin{array}{l}30,2 \pm 0,76^{* *} \\
30,3 \pm 0,70^{* *}\end{array}$ & $\begin{array}{c}30,0 \pm 0,79 * * \\
31,7 \pm 0,71 * \\
<0,2\end{array}$ & $<0,2$ \\
\hline $\begin{array}{l}\text { FR } \\
\text { before treatment } \\
\text { after treatment } \\
\text { P }\end{array}$ & $7,84 \pm 0,34$ & $\begin{array}{l}6,56 \pm 0,41 * * \\
6,84 \pm 0,28 * *\end{array}$ & $\begin{array}{c}6,34 \pm 0,32 * * \\
7,03 \pm 0,35 * \\
<0,2\end{array}$ & - \\
\hline
\end{tabular}

Notes:

1) $\mathrm{P}$ - probability of difference of indices before and after treatment;

2) $\mathrm{P}_{1-2}$ - probability of difference of data after treatment between different MC;

3) * Tendency to changes of indices compared with the control;

4) ** Valuable changes of indices compared with the control.

Analyzing the treatment' influence on cellular immunity indices it was found that effect was enough expressed for both MC (Table 3). This effect manifested in significant increase in the level of $\mathrm{T}$ lymphocytes and $\mathrm{CD}^{+}$-cells in the background of decrease in 0-lymphocytes number and the ratio of $\mathrm{CD}^{+} / \mathrm{CD}^{+}$to normal values. It must be underlined that after the $\mathrm{MC}-2$ the increase of $\mathrm{CD}^{+}$level was more expressed, indicating the restoration of normal relation of the main 
subpopulations of T-lymphocytes, certain normalization of $\mathrm{T}$-cell differentiation and fading the autoimmune inflammation symptoms. At the same time, the level of B-lymphocytes in the group of patients treated according to MC-1 had a tendency to decrease whereas in another group treated using $\mathrm{MC}-2$ their level decreased significantly. However, in both cases the number of $\mathrm{CD} 22^{+}$-lymphocytes remained significantly higher than normal, indicating the presence of antigenic load on the body.

TABLE 3: Dynamics of cellular immunity indices at patients with psoriasis under the influence of recovery treatment

\begin{tabular}{|c|c|c|c|c|}
\hline Indices and their units & $\begin{array}{l}\text { The control group } \\
(\mathrm{n}=23)\end{array}$ & $\begin{array}{l}\mathrm{MC}-1 \\
(\mathrm{n}=32)\end{array}$ & $\begin{array}{l}\mathrm{MC}-2 \\
(\mathrm{n}=32)\end{array}$ & $P_{1-2}$ \\
\hline $\begin{array}{l}\mathrm{CD}^{+}, \% \\
\text { before treatment } \\
\text { after treatment } \\
\text { P }\end{array}$ & $66,4 \pm 0,59$ & $\begin{array}{c}59,8 \pm 0,78 * * \\
62,5 \pm 0,42 * * \\
<0,01\end{array}$ & $\begin{array}{c}59,9 \pm 1,02 * * \\
63,5 \pm 0,40 * * \\
<0,01\end{array}$ & $<0,1$ \\
\hline $\begin{array}{l}\mathrm{CD} 22^{+}, \% \\
\text { before treatment } \\
\text { after treatment } \\
\text { P }\end{array}$ & $13,6 \pm 0,31$ & $\begin{array}{c}18,9 \pm 0,65 * * \\
17,9 \pm 0,52 * * \\
<0,3\end{array}$ & $\begin{array}{c}18,6 \pm 0,58 * * \\
16,4 \pm 0,39 * * \\
<0,01\end{array}$ & $<0,05$ \\
\hline $\begin{array}{l}\text { 0-лімфоцити, \% } \\
\text { before treatment } \\
\text { after treatment } \\
\text { P }\end{array}$ & $20,2 \pm 0,67$ & $\begin{array}{c}22,4 \pm 0,92 * \\
19,6 \pm 0,85 \\
<0,05\end{array}$ & $\begin{array}{c}22,5 \pm 1,23^{*} \\
20,3 \pm 0,73 \\
<0,2\end{array}$ & - \\
\hline $\begin{array}{l}\mathrm{CD}^{+}, \% \\
\text { before treatment } \\
\text { after treatment }\end{array}$ & $37,3 \pm 0,37$ & $\begin{array}{l}35,4 \pm 0,76^{* *} \\
36,0 \pm 0,41^{* *}\end{array}$ & $\begin{array}{c}36,5 \pm 0,81 \\
36,0 \pm 0,34^{* *}\end{array}$ & - \\
\hline $\begin{array}{l}\mathrm{CD}^{+}, \% \\
\text { before treatment } \\
\text { after treatment } \\
\mathrm{P}\end{array}$ & $28,6 \pm 0,38$ & $\begin{array}{c}23,3 \pm 0,57 * * \\
26,5 \pm 0,43 * * \\
<0,01\end{array}$ & $\begin{array}{c}23,7 \pm 0,69 * * \\
27,4 \pm 0,42 * * \\
<0,001\end{array}$ & $<0,2$ \\
\hline $\begin{array}{l}\mathrm{CD}^{+} / \mathrm{CD}^{+} \\
\text {before treatment } \\
\text { after treatment } \\
\mathrm{P}\end{array}$ & $1,31 \pm 0,02$ & $\begin{array}{c}1,58 \pm 0,06 * * \\
1,35 \pm 0,04 \\
<0,05\end{array}$ & $\begin{array}{c}1,57 \pm 0,06^{* *} \\
1,33 \pm 0,03 \\
<0,001\end{array}$ & - \\
\hline
\end{tabular}

Notes:

1) $\mathrm{P}$ - probability of difference of indices before and after treatment;

2) $\mathrm{P}_{1-2}$ - probability of difference of data after treatment between different MC;

3) * Tendency to changes of indices compared with the control;

4) ** Valuable changes of indices compared with the control.

Thus it was found that the application of MC-2, compared with MC1 , resulted in the tendency to increase the levels of $\mathrm{CD}^{+}{ }^{+}, \mathrm{CD}^{+}$-cells and a significant decrease in the level of Blymphocytes. This result testified the indirect intensification of immune influence of this complex by eliminating effect of mineral water intake on the endogenous intoxication at patients with associated gastroenterological and renal disorders. 


\section{Conclusions}

Marked clinical and immunomodulative efficiency of basic medical complex including photobalneotherapy and haloerosoltherapy (MC-1) was revealed consisting in considerable regression of psoriatic rush, improving of non-specific resistance and cellular immunity indices at psoriasis patients. At the same time more pronounced dynamic of psoriasis cutaneous manifestations and indices of immune reactivity were observed under the influence of MC-2 with mineral water intake. A greater percentage of patients discharged with a significant improvement, tendency to increase NBT-test, levels of $\mathrm{CD}^{+}{ }_{-}^{-}$and $\mathrm{CD}^{+}$-lymphocytes were characteristic for this group of patients. A significant increasing the level of PhAN and reduction the number of $B$ lymphocytes was reached in comparison with the MC-1. These changes indicate a greater immuno-modulative effectiveness of this complex.

High frequency of combined visceral pathology, including digestive and urinary organs in patients with psoriasis determine the expediency of additional drinking use of bicarbonate mineral waters as a component of medical complex. Their application makes it possible to stabilize the progression of the pathologic process in the skin by correcting the disturbed functions of the digestive and urinary systems and indirect effects on the immune status.

Moreover the revealed positive dynamics of immune indices indicate the expediency of different non-medicinal methods use in order to obtain better immuno-rehabilitative effect at psoriasis patients.

\section{Bibliography}

1. Андрашко Ю.В. Використання лікувальних властивостей ропи $\mathrm{i}$ мулу озера Кунігунда в Українському Закарпатті при псоріазі // Український журнал дерматології, венерології, косметології. - 2002. - № 1. - С. 3738.

2. Боднар C.А., Ляшенко I.Н., Труніна T.I. та ін. Динаміка деяких показників ендотоксикозу у хворих на тяжкі хронічні розповсюджені дерматози в процесі використання комплексного методу ендоекологічної реабілітації та корекції // Дерматологія та венерологія. - 2006. - № 2. - С. 48 50.

3. Волнухин В.А., Вавилов А.М., Кравцова И.В., Катунина О.Р. Гистологические и иммуногистохимические изменения кожи больных псориазом при лечении ПУВА-ваннами // Вестн. дерматол., венерол. - 2007. - № 2. C. 3-7.

4. Лемко I.C., Гайсак М.О., Попович Є.B. Можливості поєднаної детоксикаційної терапії хронічних хворих в умовах бальнеологічних курортів // Український хіміотерапевтичний журнал. - 2008. - № 1-2. - С. 41-46.

5. Шано В.П., Кучер Е.А. Синдром эндогенной интоксикации // Острые и неотложные состояния в практике врача. - 2011. - №1 (25). - С. 35-41.

6. Al-Mutairi N., Al-Farag S., Al-Mutairi A. at al. Comorbidities associated with psoriasis: an experience from the Middle East. // J Dermatol. - 2010. V.37(2). - P. 146-155.

7. Augustin M., Reich K., Glaeske G. et al. Co-morbidity and age-related prevalence of psoriasis: analisis of health insurance data in Germany // Acta Derm Venerol. - 2010. - Vol.90. - P. 147-151. 
8. Cassano N., Vestita M., Panaro M. et al. Renal function in psoriasis patients // Eur J Dermatol. - 2011. - Vol. 21, N 2. - P. 264-265.

9. Constantino M., Lampa E. Psoriasis and mud bath therapy: clinicalexperimental study //Clin.Ter. - 2005. - 156 (4). - P. 145-149.

10. Farley E., Menter A. Psoriasis: comorbidities and associations // Skin Therapy Lett. - 2008. - N13 (1). - P. $1-5$.

11. Gisondi P., Del Giglio M., Cozzi A. et al. Psoriasis, the liver, and the gastrointestinal tract // Acta Dermatovenerol. Croat. - 2010. - N18(4). - P. 297-304.

12. Gudjonson J.E. Psoriasis: epidemiology // Clin.Dermatol. - 2007. - Vol.25, N6. - P. 535-546.
13. Naldy L. Family history of psoriasis, stressful life events, and recent infectious disease are risk factors for a first episode of acute psoriasis: Results of a case-control study // J.Am. Acad. Dermatol. - 2005. - V.53 (1). - P.1725.

14. Sabat R., Philipp S., Hoflich C. et al. Immunopathogenesis of psoriasis // Exp. Dermatology. - 2007. - Vol.157. - P. 165-167.

15. Ojetty V, De Simone C, Aguilar Sanches J. et. al. Maleabsortion in psoriatic patients: cause or consequence? // Scand. J. Gastroenterol. 2006. - Vol. 41. - P. 1267-1271. 